\title{
Combined effects of low light and water stress on Jatropha curcas L. promotes shoot growth and morphological adjustment
}

\author{
Isabella Christina Silveira Carneiro ${ }^{1,2}$, Eduardo Gusmão Pereira ${ }^{1}$ and João Paulo Souza ${ }^{1 *}$
}

Received: March 11, 2015 Accepted: June 3, 2015

\begin{abstract}
Jatropha curcas (physic nut) is a plant with economic and pharmaceutical uses. Basic studies on the influence of environmental factors on the early development of J. curcas are important for improving farming techniques and increasing productivity. This study investigated the adjustments of J. curcas to the environmental factors of drought and light stress in order to determine which factors most strongly affect the allocation of biomass during early growth. Leaves, stems, and roots of young plants were sampled and leaf area was measured during January and June in 2011. Plants of $J$. curcas that were grown in shade and subjected to water stress showed higher biomass allocation to aerial parts (mainly stems), which can be explained as a strategy for maximizing carbon assimilation. The pattern of biomass allocation between aerial components and the root system changed in plants grown in shade. During June 2011, biomass in shade-grown J. curcas was preferentially allocated to stems, indicating long-term adjustment. The lower biomass allocation to the root system suggests reduced exploitation of soil water even when this resource is scarce. Thus, over the long term, growth of J. curcas may be compromised by the combined effects of light stress and water deficit.
\end{abstract}

Keywords: growth, Jatropha curcas, leaf area, light stress, water deficit

\section{Introduction}

The physic nut (Jatropha curcas, Euphorbiaceae) is a multipurpose plant with economic and pharmaceutical potential. One of the most important economic use is the production of oil extracted from seeds (Gübitz et al. 1999; Augustus et al. 2002; Tiwari et al. 2007), which is used for biodiesel production. Jatropha curcas can be used as hedge plantations since it does not serve as food for cattle, additionally can be used to control soil erosion (Heller 1996), and its oil can be used to produce soap and lamp fuel (Gübtiz et al. 1999). The pharmaceutical uses are performed using the plant latex as healing, hemostatic and as a purgative (Peixoto 1973). A small tree (up to 5 meters tall), J. curcas grows in a wide range of water regimes $(200-1500 \mathrm{~mm})$ and drops its leaves when subjected to long periods of drought. However, net primary productivity of physic nut increases during periods of increased rainfall. The species is widespread because of its traits and its capacity to tolerate drought, low radiation, and low soil fertility, and its adaptability to highly variable climatic conditions (Putten et al. 2010).

In plants, stress can occur when there is a deviation from the optimal conditions for growth and development, and if the plant's thresholds for resistance and adaptability are exceeded, permanent damage or death can result. Leaf water potential and plant physiological processes including stomatal resistance, transpiration, and photosynthesis can be influenced by short-term water stress (Chapin III et al. 1987), and acclimation to different light intensities can manifest physiologically and morphologically (Chazdon et al. 1996). Shading results in reduced photosynthesis because shaded leaves are light limited and thus contribute little to overall productivity, unlike leaves exposed to full sunlight. Sun leaves have less surface area and greater weight per unit surface area than shade leaves (Almeida et al. 2005). Besides, shaded leaves show low leaf thickness, stomatal density, leaf area index than sun leaves and its leaves had horizontal orientation (Givnish 1988) than sun leaves. Shade plants can be more affected by seasonal water deficit than sun plants in function of competition of nutrients by roots and low photochemical efficiency (Valadares \& Pearcy 2002). Young plants under dry forest canopy (Khurana \& Singh 2001) and in Cerrado vegetation (Ronquim et al. 2009) develop adaptive traits such as high biomass allocation to the roots. In this way, these plants under light limitation and soil water stress allocate resources to produce new biomass to the organs that acquire the most strongly limiting resources (Chapin III et al. 1987).

Jatropha curcas plants grown in light-limited environments are taller than those grown in full sun (Costa et al.

\footnotetext{
${ }^{1}$ Instituto de Ciências Biológicas e da Saúde, Universidade Federal de Viçosa, Campus Florestal, LMG 818, Km 06, 35690-000, Florestal, Minas Gerais, Brazil ${ }^{2}$ Instituto de Ciências Biológicas, Universidade Federal de Minas Gerais, Presidente Antônio Carlos, 6627, 31270-901, Belo Horizonte, Minas Gerais, Brazil

* Corresponding author: joaopaulobio@hotmail.com
} 
2011). Deep shading can decrease photosynthetic performance and thus biomass production in J. curcas (Matos et al. 2011), but moderate shade improves temperature and humidity conditions for plant growth and can increase production of total dry mass, leaf dry mass, and leaf area (Matos et al. 2011). Jatropha curcas grown in full sun showed higher net carbon assimilation rate, quantum yield, and dissipation of excess light energy than shaded individuals (Matos et al. 2009).

Under stress, plants show long-term changes that are reflected in leaf area and biomass allocation between different crown tissues (leaves and shoots). The pattern of biomass allocation between leaves and shoots also indicate how a species optimizes resource use and determines crown architecture (Souza et al. 2009). Jatropha curcas shows significantly non-uniform growth, development, and crown architecture because this species has not been bred for genetic improvement (Albuquerque et al. 2009). Thus, basic studies of the morphology of J. curcas are necessary to obtain a better understanding of its growth and acclimation processes, which will help in the genetic improvement of this species. Experiments that examine factors such as water deficit and light stress are also important in the context of global climate change and uneven patterns of precipitation and temperature (Melillo et al. 1993; Vitousek 1994; Hughes 2000), such as increased atmospheric vapor pressure deficit.

In this study, we assessed the long-term response of $J$. curcas plants subjected to water and light stresses by determining biomass allocation among leaves, stems, and roots. Our hypothesis is that individuals of J. curcas plants growing in shade will present higher height, leaf area, specific leaf area and leaf area ratio in comparison with individuals growing under high light intensity. However, because of possible synergism between light and water stresses along experiment, individuals under these stresses could decrease production and biomass allocation to stem, roots and leaves. We expected that shade environment could improve the microclimatic conditions to growth of J. curcas plants, but when subjected to long term water stress the shade environment will become a high stressor and will impaired J. curcas development. Our findings may help in the management of $J$. curcas by improving the performance of plantings to increase their productivity.

\section{Material and Methods}

\section{Plant material, experimental and soil conditions}

Jatropha curcas L. develops as a shrub or small tree and has a lifespan of approximately 50 years. The crown architecture varies from a main stem with no branches to a main stem with branches growing from the base. Branches of J. curcas contain sticky, white latex, and the root system is well developed, with roots growing laterally and vertically into deeper soil layers. This species is resilient and can survive in temperatures from $4^{\circ}$ to $35.7^{\circ} \mathrm{C}$, annual precipitation from $440 \mathrm{~mm}$ to $3121 \mathrm{~mm}$ and in locations with short growing seasons. It can retrieves nutrients from its leaves and store them in the stem and root system (Putten et al. 2010). The leaf habit is deciduous, but the stem remains green and photosynthetically active after the plant drops its leaves (Putten et al. 2010).

Seeds of $J$. curcas used in this study were collected in the city of Janaúba, Minas Gerais, Brazil, and were stored for 5 months in plastic bags in the laboratory at $25^{\circ} \mathrm{C}$. The seeds were sterilized with a solution of $2 \%$ sodium hypochlorite $(\mathrm{NaOCl})$ for $2 \mathrm{~min}$ and then were washed with distilled water. The sterilized seeds were placed on germination paper moistened with deionized water and were maintained in a germination chamber $\left(28^{\circ} \mathrm{C}, 100 \%\right.$ relative humidity, 12-h photoperiod) for 9 days. After germination, healthy seedlings were selected according to morphological homogeneity and were transferred to plastic pots containing $8 \mathrm{~L}$ of soil. The soil used in the experiment was classified as mesotrophic. The soil chemical characteristics at the beginning of the experiment were: $26 \mathrm{~g} \mathrm{dm}^{-3}$ of total organic matter, $\mathrm{pH}$ value 5.25 under water, cation exchange capacity $7.13 \mathrm{cmol}_{c} \mathrm{dm}^{-3}$ and saturation base (V\%) equal to $34.1,2.20$ and $135 \mathrm{mg} \mathrm{dm}^{-3}$ of phosphorus and potassium, respectively, and 1.53 and $0.55 \mathrm{cmol}_{c} \mathrm{dm}^{-3}$ of calcium, and magnesium, respectively.

The experiment was performed in a greenhouse with four treatments designed to assess the interactions between light stress and drought. Ten plants were maintained under full sunlight with daily watering (Sun + daily watering, DW); 10 plants were kept under full sunlight with cyclical suspension of watering (Sun + water stress, WS); 10 plants were grown under $70 \%$ shade tissue with daily watering (Shade, light stress + DW); and 10 plants were covered with $70 \%$ shade tissue with cyclical suspension of watering (Shade, light stress + WS). In the water-stress treatments, plants were kept without irrigation until signs of stress were evident (e.g., leaf tipping and wilting), after which the plants were irrigated to soil field capacity. Thus, we investigated the individual and synergistic effects of the stresses. Sampling was performed in 2011 at 210 days after sowing (DAS, January) and 360 DAS, in June.

\section{Biometry, leaf area, shoot and leaf dry mass}

We recorded weekly the plant height and petiole length in five plants per treatment using a millimeter ruler, and we measured the diameter of the stem base (approximately $2 \mathrm{~cm}$ from ground level) using a vernier caliper. The number of leaves was also recorded weekly. These traits were measured from October 2010 to June 2011.

Another group of five plants per treatment was used for destructive measurements of stem, root, and leaf dry weight and leaf area. Stem dry weight was determined after removing all lateral buds and leaves, and the area and weight of the removed leaves was determined. Leaf area was determined 
using Image Pro version 4.0 (Media Cybernetics, Rockville, $\mathrm{MD})$. Stems, roots, and leaves were dried out at $70^{\circ} \mathrm{C}$ to constant weight (Cornelissen et al. 2003) and their masses were measured with a precision balance. Before drying, the length of stems and roots was measured with a millimeter ruler. All leaves were assessed, regardless of size and age. The leaf area per stem (individual) was obtained from the sum of the leaf areas for that stem, and total leaf area and the mass of stems, roots, and leaves were determined on a per-plant basis.

\section{Shoot-foliage relationships}

The following biometric indices were calculated from the measured morphological characteristics: specific leaf area (leaf area / leaf mass; $\mathrm{cm}^{2} \mathrm{~g}^{-1}$ ); weight-based root-tostem ratio (root dry mass / stem dry mass; g); length-based root-to-stem ratio (root length / stem length; $\mathrm{cm}$ ), leaf area ratio (LAR; total leaf area / total dry mass; $\mathrm{cm}^{2} \mathrm{~g}^{-1}$ ) and leaf display index (leaf area per stem length; $\mathrm{cm}^{2} \mathrm{~cm}^{-1}$ ). These morphological indices show the distribution of foliage in the plant crown and the optimization of biomass allocation among stems, roots, and leaves (Yagi \& Kikuzawa 1999; Yagi 2000; Souza et al. 2009). The distribution of foliage also indicates how the plant uses available resources and adjusts to stresses such as drought and shade.

\section{Statistical analyses}

The experiment followed a factorial $(2 \times 2)$ design with two conditions of luminosity (full sun and shade) and two levels of water availability (water stress and well watered). We calculated the mean and standard error for all morphological and biometric indices ( $\mathrm{n}=5$ plants per treatment) and used two-way analysis of variance (ANOVA). The means were compared by Tukey's test at $5 \%$ probability with SAEG 9.1-UFV software (Fundação Arthur Bernardes, UFV, Viçosa, 2007). Only when required the data were grouped into sub-divided parcels, with each parcel representing the time of sampling. We do not compare the temporal differences related to leaf parameters among treatments, once plants grown in full sun lost their leaves in June 2011.

\section{Results}

Water stress in combination with exposure to shade affected leaf area and stem length during the first data collection (January 2011). The effect of water stress on average leaf area was more severe in plants exposed to full sunlight with reduced dry masses of stem, roots, and leaves (Tab. 1). In June 2011, second data collection, all J. curcas plants grown in full sun lost their leaves, and shade-grown plants exposed to water stress had reduced leaf area and leaf dry

Table 1. Morphological traits of physic nut (Jatropha curcas L.) subjected to light and water stresses during January and June 2011. ANOVA results are presented in the rows below each season's data. Significance levels are indicated as follows: ${ }^{\star}, \mathrm{p}<0.05 ;{ }^{* *}, \mathrm{p}<0.01$; ${ }^{* *}, \mathrm{p}<0.001$; ns, not significant. Significant differences are indicated by different capital or lower case letters: capital letters compare sun versus shade treatments, and lowercase letters compare well-watered (WW) versus water-stressed (WS) treatments (Tukey's test, $\alpha=0.05$ ). Data are means \pm standard error of five replicates.

Morphological traits

January 2011

\begin{tabular}{|c|c|c|c|c|c|c|c|c|c|}
\hline Treatments & & $\begin{array}{l}\text { Average leaf } \\
\text { area }\left(\mathrm{cm}^{2}\right)\end{array}$ & $\begin{array}{l}\text { Total leaf area } \\
\qquad\left(\mathrm{cm}^{2}\right)\end{array}$ & $\begin{array}{l}\text { Stem dry } \\
\text { mass (g) }\end{array}$ & $\begin{array}{l}\text { Root dry } \\
\text { mass (g) }\end{array}$ & $\begin{array}{l}\text { Leaf dry } \\
\text { mass (g) }\end{array}$ & $\begin{array}{l}\text { Total dry } \\
\text { mass }(g)\end{array}$ & $\begin{array}{l}\text { Stem length } \\
(\mathrm{cm})\end{array}$ & $\begin{array}{l}\text { Root length } \\
(\mathrm{cm})\end{array}$ \\
\hline \multirow{2}{*}{ Sun } & WW & $49.6 \pm 5.2 \mathrm{Ba}$ & $367.3 \pm 47.7 \mathrm{Ba}$ & $2.9 \pm 0.4$ & $1.5 \pm 0.2$ & $1.3 \pm 0.1$ & $5.8 \pm 0.7$ & $13.4 \pm 0.8 \mathrm{Ba}$ & $13.0 \pm 0.4$ \\
\hline & WS & $26.9 \pm 1.5 \mathrm{Bb}$ & $203.0 \pm 20.4 \mathrm{Ba}$ & $1.9 \pm 0.4$ & $1.0 \pm 0.2$ & $0.8 \pm 0.1$ & $3.6 \pm 0.7$ & $10.3 \pm 1.1 \mathrm{Ba}$ & $11.9 \pm 1.0$ \\
\hline \multirow{2}{*}{ Shade } & WW & $97.5 \pm 2.2 \mathrm{Aa}$ & $757.9 \pm 75.9 \mathrm{Aa}$ & $3.2 \pm 0.5$ & $1.2 \pm 0.1$ & $1.5 \pm 0.1$ & $6.0 \pm 0.5$ & $16.5 \pm 1.3 \mathrm{Aa}$ & $15.0 \pm 0.6$ \\
\hline & WS & $104.4 \pm 7.4 \mathrm{Aa}$ & $922.7 \pm 63.5 \mathrm{Aa}$ & $2.5 \pm 0.4$ & $0.9 \pm 0.1$ & $1.2 \pm 0.1$ & $4.6 \pm 0.6$ & $18.5 \pm 1.3 \mathrm{Aa}$ & $12.0 \pm 0.5$ \\
\hline Light (L) & & $* * *$ & $* * *$ & ns & ns & * & ns & $* * *$ & ns \\
\hline Water (W) & & ns & ns & * & $* *$ & $* *$ & * & ns & * \\
\hline $\mathbf{L} \times \mathbf{W}$ & & $* *$ & $* *$ & ns & ns & ns & ns & * & ns \\
\hline \multicolumn{10}{|l|}{ June 2011} \\
\hline Treatments & & $\begin{array}{l}\text { Average leaf } \\
\text { area }\left(\mathrm{cm}^{2}\right)\end{array}$ & $\begin{array}{l}\text { Total leaf area } \\
\qquad\left(\mathrm{cm}^{2}\right)\end{array}$ & $\begin{array}{l}\text { Stem dry } \\
\text { mass }(g)\end{array}$ & $\begin{array}{l}\text { Root dry } \\
\text { mass }(g)\end{array}$ & $\begin{array}{l}\text { Leaf dry } \\
\text { mass (g) }\end{array}$ & $\begin{array}{l}\text { Total dry } \\
\text { mass }(g)\end{array}$ & $\begin{array}{l}\text { Stem length } \\
(\mathrm{cm})\end{array}$ & $\begin{array}{l}\text { Root length } \\
(\mathrm{cm})\end{array}$ \\
\hline \multirow{2}{*}{ Sun } & WW & - & - & $4.2 \pm 0.9$ & $2.4 \pm 0.3 \mathrm{Ba}$ & - & $6.5 \pm 1.3 \mathrm{Ba}$ & $13.6 \pm 1.4$ & $13.4 \pm 1.2$ \\
\hline & WS & - & - & $2.5 \pm 0.3$ & $1.6 \pm 0.2 \mathrm{Bb}$ & - & $4.1 \pm 0.4 \mathrm{Bb}$ & $12.8 \pm 0.6$ & $13.0 \pm 0.9$ \\
\hline \multirow{2}{*}{ Shade } & WW & $102.8 \pm 5.8$ & $777.5 \pm 33.6$ & $21.1 \pm 2.2$ & $10.2 \pm 1.2 \mathrm{Aa}$ & $1.7 \pm 0.1$ & $33.0 \pm 3.3 \mathrm{Aa}$ & $25.6 \pm 1.6$ & $14.1 \pm 0.8$ \\
\hline & WS & $68.8 \pm 32.0$ & $137.1 \pm 64.3$ & $15.4 \pm 1.2$ & $6.0 \pm 0.2 \mathrm{Ab}$ & $0.5 \pm 0.1$ & $21.9 \pm 1.4 \mathrm{Ab}$ & $28.4 \pm 2.2$ & $15.0 \pm 0.6$ \\
\hline Light (L) & & - & - & $* * *$ & $* * *$ & - & $* * *$ & * & ns \\
\hline Water (W) & & ns & $* * *$ & $* *$ & ** & $* * *$ & $* *$ & ns & ns \\
\hline $\mathbf{L} \times \mathbf{W}$ & & - & - & ns & * & - & * & ns & ns \\
\hline
\end{tabular}


mass relative to plants grown in shade with adequate water supply (Tab. 1). There were no differences in root length among treatments.

High light exposure had significant effects on all biometric indices in the January and June 2011. In January 2011, the highest leaf display index, specific leaf area, and LAR occurred in plants grown in shade (Tab. 2). At this time, significant increases in LAR in water-stressed treatments occurred only in shade-grown plants. In contrast, reduced LAR occurred in shade-grown plants subjected to water stress in June (Tab. 2). The lowest root-to-stem ratio occurred in plants grown in shade during both evaluation periods. The root-to-stem ratio (mass basis) increased in June 2011, but on a length basis, the root-to-stem ratio decreased relative to January. The leaf display index increses in June 2011 and LAR was lower in June than in January 2011 (Tab. 2). Light stress affects petiole length $(P<0,01$, ANOVA), being in shaded plants $(12.5 \mathrm{~cm})$ three times higher than in sunny plants $(4.3 \mathrm{~cm})$.

\section{Discussion}

The higher biomass allocation to stems of J. curcas plants grown in shade (June 2011) and the high investment in leaf area in shaded plants indicates that these were morphologi- cal adjustments to stress (Tabs. 1,2). These adjustments enable establishment and growth of $J$. curcas under low light conditions (Ronquim et al. 2009; Sesma et al. 2009), thus avoiding the effects of light deficit (Bloom et al. 1985). Species that develop in shaded environments have strategies for increasing the area of tissues that can absorb light (Givnish 1988; Almeida et al. 2005). According to Costa et al. (2011) and Sesma et al. (2009), J. curcas plants subjected to 50\% shading showed greater height, leaf area, and total dry mass than plants grown in full sun. These authors suggested that better performance of shaded J. curcas could be related to better temperature and humidity conditions in the shade. However biomass allocation can vary as a result of distinct genetic traits leading to different physiological adjustments.

However, when shaded J. curcas plants were subjected to long-term cycles of water deficit, biomass allocation to roots was reduced by more than $40 \%$ (Tab. 2), but root length did not change under water stress, so access to the soil water was maintained. This effect of water stress on biomass allocation to roots indicates that the combination of shade and drought could impair plant development under long-term exposure to shade. The decreased biomass allocation to roots could also be caused by faulty translocation of photoassimilates from leaves to roots in shaded plants (Lee et al. 1997). This indicates that J. curcas is adapted to dry conditions; however, this vegetative growth was not associated with production

Table 2. Biometric indices in physic nut plants (Jatropha curcas L.) during January and June 2011. ANOVA results are presented in the rows below each season's data. Significance levels are indicated as follows: ${ }^{*}, \mathrm{p}<0.05 ;{ }^{* *}, \mathrm{p}<0.01 ;{ }^{* * *}, \mathrm{p}<0.001 ;$ ns, not significant. Significant differences are indicated by different capital or lower case letters: capital letters compare sun versus shade treatments, and lower case letters compare well-watered (WW) versus water-stressed (WS) treatments (Tukey's test, $\alpha=0.05$ ). Data are means \pm standard error of five replicates.

Biometric indices

January 2011

\begin{tabular}{|c|c|c|c|c|c|c|}
\hline Treatments & & $\begin{array}{l}\text { Leaf display index } \\
\qquad\left(\mathrm{cm}^{2} \mathrm{~cm}^{-1}\right)\end{array}$ & $\begin{array}{l}\text { Specific leaf area } \\
\qquad\left(\mathrm{cm}^{2} \mathrm{~g}^{-1}\right)\end{array}$ & $\begin{array}{c}\text { Root/stem ratio } \\
(\mathrm{cm})\end{array}$ & $\begin{array}{c}\text { Root/stem ratio } \\
\text { (g) }\end{array}$ & $\begin{array}{l}\text { Leaf area ratio } \\
\qquad\left(\mathrm{cm}^{2} \mathrm{~g}^{-1}\right)\end{array}$ \\
\hline \multirow{2}{*}{ Sun } & WW & $3.7 \pm 0.2$ & $40.0 \pm 2.9 \mathrm{Ba}$ & $1.0 \pm 0.1 \mathrm{Aa}$ & $0.5 \pm 0.0$ & $63.5 \pm 4.0 \mathrm{Ba}$ \\
\hline & WS & $2.8 \pm 0.4$ & $36.8 \pm 4.3 \mathrm{Ba}$ & $1.2 \pm 0.2 \mathrm{Aa}$ & $0.5 \pm 0.1$ & $61.7 \pm 9.0 \mathrm{Ba}$ \\
\hline \multirow{2}{*}{ Shade } & WW & $6.1 \pm 0.5$ & $65.2 \pm 4.6 \mathrm{Aa}$ & $0.9 \pm 0.1 \mathrm{Aa}$ & $0.4 \pm 0.1$ & $128.5 \pm 12.7 \mathrm{Ab}$ \\
\hline & WS & $5.8 \pm 0.8$ & $88.8 \pm 8.3 \mathrm{Aa}$ & $0.6 \pm 0.0 \mathrm{Ba}$ & $0.3 \pm 0.0$ & $208.1 \pm 22.8 \mathrm{Aa}$ \\
\hline Light (L) & & $* * *$ & $* * *$ & * & * & $* * *$ \\
\hline Water $(W)$ & & ns & ns & ns & ns & * \\
\hline $\mathbf{L} \times \mathbf{W}$ & & ns & * & * & ns & * \\
\hline \multicolumn{7}{|l|}{ June 2011} \\
\hline Treatments & & $\begin{array}{l}\text { Leaf display index } \\
\qquad\left(\mathrm{cm}^{2} / \mathrm{cm}^{-1}\right)\end{array}$ & $\begin{array}{l}\text { Specific leaf area } \\
\qquad\left(\mathrm{cm}^{2} \mathrm{~g}^{-1}\right)\end{array}$ & Root/stem ratio $(\mathrm{cm})$ & Root/stem ratio (g) & $\begin{array}{l}\text { Leaf area ratio } \\
\qquad\left(\mathrm{cm}^{2} \mathrm{~g}^{-1}\right)\end{array}$ \\
\hline \multirow{2}{*}{ Sun } & WW & - & - & $1.0 \pm 0.1$ & $0.7 \pm 0.1$ & - \\
\hline & WS & - & - & $1.0 \pm 0.1$ & $0.6 \pm 0.1$ & - \\
\hline \multirow{2}{*}{ Shade } & WW & $33.0 \pm 3.3$ & $58.8 \pm 3.3$ & $0.6 \pm 0.1$ & $0.5 \pm 0.0$ & $24.7 \pm 3.0$ \\
\hline & WS & $21.9 \pm 1.4$ & $150.8 \pm 70.2$ & $0.5 \pm 0.1$ & $0.4 \pm 0.0$ & $5.7 \pm 2.6$ \\
\hline Light (L) & & - & - & $* * *$ & * & - \\
\hline Water (W) & & ns & ns & ns & ns & $* *$ \\
\hline $\mathbf{L} \times \mathbf{W}$ & & - & - & ns & ns & - \\
\hline
\end{tabular}


(flowers and fruits) because the plants were not mature (Albuquerque et al. 2009).

Developmental impairment of J. curcas resulting from synergy between stresses was revealed when plants under full sun were subjected to water stress. Jatropha curcas plants have reduced leaf area when grown in dry conditions (Albuquerque et al. 2009) or under full irradiance (Matos et al. 2009). Here, we have shown the combined effects of light stress and water deficit on this species for the first time.

Leaf size was significantly reduced in plants grown under full sun and water stress relative to that of plants grown in shade (Tab. 1). Water stress affects cell turgor, which limits leaf growth and development (Fahn et al. 1990). Thus, the lower evaporative demand under shade conditions may have contributed to the maintenance of leaf size under water stress. Changes in biomass allocation in relation to unchanged leaf area in these plants demonstrate a close relationship between the water and carbon balance during periods of water deficit.

Considering the optimal maximum temperature $\left(31.5-34.0^{\circ} \mathrm{C}\right.$ ) in the natural range of J. curcas (Maes et al. 2009), we suggest that J. curcas grown in full sun lost their leaves during June 2011 because of high temperatures (at this time range from $40^{\circ} \mathrm{C}$ to $50^{\circ} \mathrm{C}$ ). Thus, shaded plants accumulated more biomass in June 2011 (second sampling), which resulted in a positive carbon balance for these plants. This response allows plants grown in shade to minimize the growth-limiting effects of drought. However, during the second evaluation period, the reduction in root dry mass in shade-grown plants was higher $(-42 \%)$ under water stress than under full sun $(-33 \%)$, indicating that even under drought, plants grown in shade spend more resources on shoot growth, as demonstrated by the root/stem ratio $(\mathrm{cm})$.

Biomass allocation to foliage in plants in shaded dry environments ensures more chance of light capture for photosynthesis (Ronquim et al. 2009). Accordingly, J. curcas adapt to low light availability by growing toward the light to maintain photosynthesis. The higher leaf display index and leaf area ratio in January 2011 in shade-grown J. curcas indicated resource allocation for optimizing light interception (Yagi \& Kikuzawa 1999; Yagi 2000). Matos et al. (2009) showed that J. curcas grown in shade had higher leaf area and leaf chlorophyll content. Leaf morphophysiological adjustments can generate more surface area for light capture and absorption (high leaf chlorophyll content). Thus, shaded plants increase photosynthetic area by allocating resources to aerial tissues. Increased LAR in response to shading can offset decreased net assimilation (Hoffmann \& Franco 2003), as observed in shade-grown plants under water stress during the first measurement period.

During the second sampling period (June 2011), shaded plants had increased leaf display index and decreased LAR relative to the first sampling period (January 2011). The high leaf display index is a result of diminished stem length and continuous leaf production in shaded plants even under water deficit. However, LAR declined in plants subjected to shade and water stress because of decreased leaf area and a shift in biomass allocation to stems. The sampling in June 2011 highlighted the pattern of biomass allocation to stems in plants subjected to shade and water stress. Although $J$. curcas is cultivated under a wide range of water regimes (Maes et al. 2009), water deficit, especially during early development, could be decisive in determining plant survival and development.

The greatest mean height occurred in shade-grown plants, reflecting investment in the production of photosynthetic structures to overcome light limitation (Ortega et al. 2006). Plants grown in sun do not need to invest heavily in vertical growth for light interception because light is not a scarce resource. The fewest leaves occurred in water-deficit treatments because of senescence of old leaves. Senescence reduces water loss by leaf transpiration, and resources in old leaves can be translocated to young leaves. Jatropha curcas can retrieves nutrients from leaves and store them in the stems and roots (Putten et al. 2010). Petiole length was greater in shaded than in sun-exposed plants throughout the experiment. Jatropha curcas leaves are alternate and sub-opposite and spirally arranged, which enhances the efficiency of light capture (Albuquerque et al. 2009). High leaf area per stem in shaded plants causes intense self-shading among leaves and the longer petioles would improve sunlight capture. The phenotypic response to shade of maximizing shoot dry mass and plant height is a typical strategy for adapting to low light conditions. These responses depend on genetic traits and plant-environment interactions (Moraes Neto et al. 2000).

The global distribution of J. curcas covers a diversity of climatic conditions (Maes et al. 2009), but it is predominately found in tropical savannas and tropical monsoon climates. According to Maes et al. (2009), J. curcas is common in regions where rainfall exceeds $944 \mathrm{~mm}$ year ${ }^{-1}$. Experiments examining light conditions show that J. curcas grown in sunny areas develop better than those grown in shade (Matos et al. 2009; 2011). However, J. curcas cannot be classified as an obligatory heliophyte because plants grown in 50\% shade perform better than those grown in full sun (Costa et al. 2011). Thus, J. curcas can withstand low light regimes or moderate water stress, but the co-occurrence of these stresses, as investigated here, can result in decreased development.

\section{Conclusion}

Under the combined stress of water deficit and low light, patterns of biomass allocation in J. curcas are altered in favor of stems to offset a potential decrease in carbon assimilation. Productivity is linked to photosynthetic capacity, and biomass allocation is related to plant development. Thus, under water stress, J. curcas plants grew better in shade than in full sun. However, plant development may be impaired by long-term shade and drought because of synergistic effects between these stresses. 


\section{Acknowledgements}

We thank to CNPq and MEC/SESU (PET) for scholarship to authors ISCS and JPS, respectively, and to FAPEMIG by financial support for this research.

\section{References}

Albuquerque FA, Castro NHA, Beltrão NEM, et al. 2009. Análise de crescimento inicial do Jatropha curcas em condições de sequeiro. Revista Brasileira de Oleaginosas e Fibrosas 13: 99-106.

Almeida SMZ, Soares AM, Castro EM, Vieira CV, Gajego EB. 2005. Alterações morfológicas e alocação de biomassa em plantas jovens de espécies florestais sob diferentes condições de sombreamento. Ciência Rural 35: 62-68.

Augustus GDPS, Jayabalan M, Seiler GJ. 2002. Evaluation and bioinduction of energy components of Jatropha curcas. Biomass and Bioenergy 23: 161-164.

Bloom AJ, Chapin III FS, Mooney HA. 1985. Resource limitation in plants - an economic analogy. Annual Review of Ecology and Systematics 16: 363-392.

Chapin III FS, Bloom AJ, Field CB, Waring RH. 1987. Plant responses to multiple environmental factors. BioScience 37: 49-57.

Chazdon RL, Pearcy RW, Lee DW, Fetcher N. 1996. Photosynthetic responses of tropical forest plants to contrasting light environments. In: Mulkey SS, Chazdon RL, Smith AP. (eds.) Tropical forest plant ecophysiology. New York, Chapman \& Hall. p. 5-55.

Cornelissen JHC, Lavorel S, Garnier E, et al. 2003. A handbook of protocols for standardised and easy measurement of plant functional traits worldwide. Australian Journal of Botany 51: 335-380.

Costa JL, Lima RP, Silva ALL, Scheidt GN, Erasmo EAL.2011. Crescimento inicial de plantas de pinhão manso em função do sombreamento no município de Gurupi-TO. Journal of Biotechnology and Biodiversity 2: 43-47.

Fahn A. Plant anatomy. 1990. Oxford, Pergamon Press.

Givnish TJ. 1988. Adaptation to sun and shade: a whole-plant perspective. Australian Journal of Plant Physiology 15: 63-92.

Gübitz GM, Mittelbach M, Trabi M. 1999. Exploitation of the tropical oil seed plant Jatropha curcas L. Bioresource Technology 67: 73-82.

Heller J. 1996. Physic nut. Jatropha curcas L. Promoting the Conservation and use of Underutilized and Neglected Crops. I. Gatersleben/ Rome, Institute of Plant Genetics and Crop Plant Research/International Plant Genetic Resources Institute.

Hoffmann WA, Franco AC. 2003.Comparative growth analysis of tropical forest and savanna woody plants using phylogenetically independent contrasts. Journal of Ecology 91: 475-484.

Hughes L. 2000. Biological consequences of global warming: is the signal already? Tree 15: 56-61.

Khurana E, Singh JS. 2001. Ecology of seed and seedling growth for conservation and restoration of tropical dry forest: a review. Environmental Conservation 1: 39-52.
Lee DW, Oberbauer SF, Johnson P, et al. 1997. Effects of irradiance and spectral quality on seedling development of two southeast Asian Hopea species. Oecologia 110: 1-9.

Maes WH, Trabucco A, Achten WMJ, Muys B. 2009. Climatic growing conditions of Jatropha curcas L. Biomass and Bioenergy 33: 1481-1485.

Matos FS, Moreira CV, Missio RF, Dias LAS. 2009. Caracterização fisiológica de mudas de J. curcas L. produzidas em diferentes níveis de irradiância. Revista Colombiana de Ciências Hortícolas 3: 126-134.

Matos FS, Gamboa I, Ribeiro RP, et al. 2011. Influência da intensidade luminosa no desenvolvimento de mudas de Jatropha curcas L. Revista Agrarian 4: 265-272.

Melillo JM, McGuire AD, Kicklighter DW, Moore B, Vorosmarty CJ, Schloss AL. 1993. Global climate change and terrestrial net primary production. Nature 363: 232-240.

Moraes Neto SP, Gonçalves JLM, Takaki M, Cenci S, Gonçalves JC. 2000. Crescimento de mudas de algumas espécies arbóreas que ocorrem na mata atlântica em função do nível de luminosidade. Revista Árvore 24: $35-45$

Ortega AR, Almeida LS, Maia N, Angelo AC. 2006. Avaliação do crescimento de mudas de Psidium cattleianum Sabine a diferentes níveis de sombreamento em viveiro. Cerne 12: 300-308.

Peixoto AR. 1973. Plantas oleaginosas arbóreas. São Paulo, Nobel.

Putten E, Franken YJ, Jongh J. 2010. General data on Jatropha. In: Jongh J. (ed.) The Jatropha handbook: from cultivation to application. Netherlands, FACT Foundation. p. 1-7.

Ronquim CC, Prado CHBA, Souza JP. 2009. Growth, photosynthesis and leaf water potential in young plants of Copaifera langsdorffii Desf. (Caesalpiniaceae) under contrasting irradiances. Brazilian Journal of Plant Physiology 21: 197-208.

Sesma RB, Demuner VG, Hebling SA. 2009. Efeito de diferentes níveis de sombreamento sobre o crescimento inicial de Jatropha curcas L. em casa de vegetação. Natureza Online 7:31-36.

Souza JP, Prado CHBA, Albino ALS, Damascos MA. 2009. Shoot-foliage relationships in deciduous, semideciduous, and evergreen cerrado tree species. Brazilian Journal of Plant Physiology 21: 75-86.

Tiwari AK, Kumar A, Raheman H. 2007. Biodiesel production from jatropha oil (Jatropha curcas) with high free fatty acids: an optimized process. Biomass and Bioenergy 31: 569-575.

Valladares F, Pearcy RW. 2002. Drought can be more critical in the shade than in the sun: a field study of carbon gain and photo-inhibition in a Californian shrub during a dry El Niño year. Plant, Cell and Environment 25: 749-759.

Vitousek PM. 1994. Beyond global warming: ecology and global change. Ecology 75: 1861-1876.

Yagi T, Kikuzawa K. 1999. Patterns in size-related variations in currentyear shoot structure in eight deciduous tree species. Journal of Plant Research 112: 343-352.

Yagi T. 2000. Morphology and biomass allocation of current-year shoots of ten tall species in cool temperate Japan. Journal of Plant Research 113: 171-183. 